\title{
Comparison of Primary School Foreign Language Curricula of Turkey, Germany and the Netherlands
}

\author{
Yasin Aslan \\ Correspondence: Yasin Aslan, Asst. Prof. Dr., Faculty of Education, Sinop University, Sinop, Turkey.
}

Received: April 15, 2016 Accepted: April 25, $2016 \quad$ Online Published: April 27, 2016

doi:10.11114/jets.v4i8.1581 URL: http://dx.doi.org/10.11114/jets.v4i8.1581

\begin{abstract}
Foreign language education at early ages involves a broad spectrum of communication skills using communication, culture, connections, comparisons and community. The aim of this study is to compare the primary foreign language curricula of Turkey, Germany and the Netherlands in terms of objectives, content, teaching processes and evaluation systems. This is a comparative education research and most of the data, taken from official sources of the country, was obtained by the document analysis. Turkish Primary School English program is found to be more comprehensive and elaborate while the program in Germany and the Netherlands are quite flexible. The curricula of Germany and the Netherlands not only provide more freedom with teachers in planning lessons but also meet the needs and interests of students. In all three countries, the programs vary in terms of content presentation. Turkey has a detailed content of the English curriculum, and teachers are obliged to follow the program. On the other hand, teachers in the Netherlands are given the opportunity to make the choice of content.
\end{abstract}

Keywords: foreign language education, curriculum and instruction, primary school foreign language curricula

\section{Introduction}

Language education not only contributes to students' career, but it also helps develop the individual as language learners take on a new and more invigorating view of the world. Students start to understand the world better thanks to their knowledge of speakers of another language - of people who share many of the same hopes and dreams for their future. While objectives, methods, programs and perspectives differ among speakers of diverse languages, there are more similarities than we might imagine. This can only be maintained through learning and understanding the language of others that we can truly understand how they view the world.

Training and development in the development of a country is known to have a significant place in reality. Therefore, countries have begun to draw special attention to education to ensure continuity and to keep up with the progress of scientific and technological developments in the world, which can only be achieved by raising the quality of education. This depends on practical, sustainable and qualified training programs within the education system of each country. Accordingly, the basic requirements of training program should be appropriate for the needs and interests of students, teachers and schools.

Program development experts in every country must be aware of keeping pace with global technological developments, searching for the programs of other countries, finding out necessary solutions to problems that may arise in the development of educational programs concerning the basic elements of the education system, examining ideas and determining possible solutions to potential problems. In other words, information sharing is realized by comparison with other countries to benefit from the experience of other countries and is important for us to review how we provide training in questioning our own education system. Such studies conducted in the field of education are included in the comparative education.

The changes in recent times require community to outreach and public relations of the increasing speed of the increasing development. Thus, people feel themselves insufficient and a need for learning a foreign language arises to communicate in their mother tongue. Learning other languages and understanding the culture of the people who speak them is a distinctive skill of $21^{\text {st }}$ century. It is crucial to succeed in the global environment in which our students will live and work. Foreign language learning is gaining publicity day by day and increasing inter-community relations in parallel with the development of mass media and maintains its topicality as well today as it was in the past.

Different approaches can be applied at different times according to the needs of foreign language teaching methods. 
Firstly, grammar-translation method was widely used in foreign language teaching in Turkey. Due to limitations, this method is replaced by a method of induction in the 1950s. Then the ear-lingual language skills were commonly taught. From 1970 to onwards, communicative approach has gained popularity in education system. Based on the communicative approach, the lack of a single optional method is adopted today.

Curriculum, a unified approach to the teaching and learning of languages, is essential. This point of view draws attention to the similarities and differences of teaching and learning in the English Curriculum and various cultures in the community. A focus on language awareness gives opportunities to bring a considerable measure of integration to language teaching and learning across the curriculum, its goal being the awakening to languages.

In addition to aptitudes for listening, analysing and learning languages, awakening to languages also aims to promote the development of favourable perceptions of and attitudes towards not only the languages and their diversity but also those who speak the languages and their cultures. Naturally this applies all the more to the languages and cultures of immigrant or native pupils, who are thus recognised by the school. Beyond its contribution to language learning, the awakening to languages represents a facet of the Feasibility and Futures Report intercultural approach, of which it is an integral part along with its specificities (Candelier, 2004).

\subsection{Problem Status}

Education has become an effective instrument to strive poverty and inequality in modern societies. It is also used for laying the foundation for a sustainable growth and development of any nation. Primary education is the core of development. It is the level of education that develops in the individual the capacity to read, write and calculate. In other words, it helps to eradicate illiteracy, which is one of the strongest predictors of poverty (Bruns, et al, 2003). Primary education is the largest sub-sector of any education system and offers the unique opportunity to contribute to the transformation of societies by means of the education of children. Primary education is the only level of education that is available everywhere in both the developed and the developing countries as well as in urban and rural areas (Akinbote, 2001). In some European countries, even in developed ones, primary and secondary schools are not prepared for the change in curriculum for language teaching. Primary and secondary schools in Turkey are anxious that they will not meet new standards and requirements of European Union to teach languages in a more effective way such as English and German.

\subsection{Research Objective}

The aim of this study is to compare the primary foreign language curricula of Turkey, Germany and the Netherlands in terms of objectives, content, teaching processes and evaluation systems.

\section{Method}

This study is a comparative education study. With the purpose of producing solutions to develop an effectual foreign language curriculum in primary schools, we tried to compare the primary foreign language curricula of Turkey, Germany and the Netherlands in terms of objectives, content, teaching processes and evaluation systems. Most of the data was taken from official sources of the country and obtained by the document analysis.

\subsection{Education in Turkey}

Foreign language policy regarding English has implications for language planning, which are designed to promote the quality of language acquisition and they result with economic, social and cultural development of the country. Foreign language teachers should be professionally well-trained and competent to close the gap between policy rhetoric and classroom reality. However, it is insufficient to have competent and well-trained teachers to imply the policy issues in practice. Curricula, textbooks, teaching methods and approaches that are determined by language policy makers affect the success of foreign language education of Turkey. Students graduate from private schools and universities with English medium instruction are luckier than the other students. On the other hand, English medium instruction is widely discussed at the national level, and thus, some universities prefer to deliver courses in Turkish.

All responsibility for the functioning of the education system in Turkey belongs to the Ministry of Education. Ministry of National Education, Ministry of Law No: 3797 on the Organization and Duties by central, provincial, consists of international organizations and affiliates. managers at all levels of the Ministry are responsible to manage the higher level of conduct duly their duties, but top executives, limit the writing clearly a part of the authorities if they indicate they can be transferred to the lower level. Ministry's central organization at the national level, the Ministry Authority, Board of Education, primary service units (General Directorate of Primary Education, Secondary Education General Directorate, etc.), is composed of units to help with counselling and supervision units. Pre-school, primary education, secondary education institutions are run under the responsibility of the ministry to open. Supervision and control of schools is carried out by the inspection committee attached to the Ministry of Education. Teacher assignment and relocation, the creation of educational programs, such as the determination of educational policy and business 
transactions carried out by the ministry (Erdem, 2007).

At the local level, in every province and one affiliated to the Ministry of National Education Directorate in the county. National Education Directorate is responsible for managing education here. District Education Directorates are accountable to the Provincial Directorate of National Education in terms of functions and services. Directorates carry out their educational services in some cities and towns (Yildirim, 2010).

The level of educational institutions belongs to the school administration management in schools. All schools are connected to the Directorate of Education. Schools, authorities and powers in determining the issue of creating its own staff and its own resources are very limited. Therefore, both are dependent on the central organization in terms of staff and budget. Anatolia centres with teachers by type of school principals, the principals of the schools other than those appointed by the governor (Eurydice, 2009).

The basic law governing the educational affairs in Turkey 1739 is the Basic Law of National Education. This is according to the law and the formal education system is divided into two parts, namely common. Formal education, preschool, elementary, consists of four levels, including secondary and higher education.

Turkish education system pre-school age from 3-5, 6- to 14 years elementary, secondary school aged 14-17 and 18 and older indicate their tertiary education. Compulsory education lasts 8 years and covers primary education. In Turkey, it was also included in the pre-school education and compulsory education has begun to gradually spread throughout the country for the pilot. However, it has not been applied in a lot of cities so far.

Pre-school education includes the optionally have come to the age of compulsory primary education of children aged 3-5. pre-school educational institutions, such as independent kindergartens, girls' vocational training institutions linked to other applications connected with the high school kindergarten classes can be opened as of. Pre-schoolers the purpose of education, children's physical, mental, emotional development and acquire good habits, the preparation of their primary conditions for the joint creation of a habitat for children from disadvantaged environments is to enable Turkish to be right and good talk (MEB, 2006).

Primary education comprises the education and training of children in the 6-14 age groups. Primary school enrolment and admission procedures to Primary Education are carried out according to the principles specified in the Regulations. The main condition for admission to primary school children starting age is. Primary, the year he graduated from the child's 5 starts at the end of September, the year of the 15 years completing his 14 years, at the end of the academic year. By law, all parents are obliged to elementary school children in a timely manner. However, who is eligible age of records but physically underdeveloped children who, upon the written request of their parents before the school can continue their education or registration may be postponed for one year. Primary education institutions consist of eight-year school, where continuous education is provided and primary school diplomas to graduates. Primary first five years of the first stage consists of two steps in the second stage of three years. Steering is done by the second stage. Primary education is compulsory for all children, boys and girls, and is free in state schools. Elementary students are made according to basic groupings and classes in schools children are in the same class at the same age as theoretical (MEB, 2010).

Primary and secondary education (9th-12 $2^{\text {th }}$ grades) covers 17 age group and 14 students. Overall, it covers all of the vocational and technical education institutions. The purpose of the students is to give a common general knowledge, individuals and communities to promote their issues and seek solutions for the country's socio-economic and giving awareness to contribute to the cultural development of their interests, talents and capabilities for higher education, to prepare them for a profession or for life and business. Secondary education consists of high schools that implement different programs and students, the opportunity to grow according to the demands and capabilities are tending to one of these programs. General and is composed of two parts, including vocational and technical education.

General secondary education, students must have a minimum general education at secondary level, that the problems of the society, the country's economy, contributing 37 people to train as a social and cultural development and aims to prepare for higher education. General secondary education, general high schools, Anatolian high schools, science high schools, Social Science High Schools, Anatolian Teacher High School Sports High School, Anatolian Fine Arts High School and is comprised of Multi-Program High School. Vocational and Technical Secondary Education, which train workforce to business and professional field, prepare students for higher education institutions. School of Technical Education for Boys, Girls Technical Education Schools, Commerce and Tourism Education Schools and Religious Education is composed of the school.

Higher Education, at least two scientific researches, mainly covers all of the four or six-year higher education institutions. There are four steps in Turkey Higher Education: associate, bachelor, masters and doctorate. Undergraduate and graduate-level students with a diploma from the University to become a secondary school exam are required to win 
the general. Secondary vocational and technical high school graduates have to pass exams to the 2-year associate degree program. Front license for at least four semesters based on secondary education (two years) covers a teaching process. Undergraduate education, secondary education based on at least eight semesters (four years) over one academic period. After the Bachelor, Master and Doctoral programs are integrated. Graduate, undergraduate education based on two semester courses, including two semesters to prepare the thesis of four semesters (two years is) a higher step. Ph.D., is the final step in the university education. $\mathrm{PhD}$ graduate education based on four semesters of coursework and thesis preparation, including at least eight semesters of four semesters (four years) encompasses a training program (Basaran, 1994: 101).

\subsection{Education in Germany}

In the Federal Republic of Germany, powers and responsibilities in the education system are determined by the federal government powers and responsibilities in the field of education, distributed among the provinces with the federal government and the responsibilities are determined basic. According to the Basic Law in the legislative and executive education is primarily the responsibility of the state. Accordingly, if the Basic Law unless it another embodiment, each province, under the shared authority and responsibility between the state and the central government, up to formal education from preschool are competent and responsible for the regulation of its education system and executed. However, the central government is responsible for the supervision of the entire school system (Saglam, 1999).

The implementation of educational affairs in the Ministry of Education and Research is responsible for the federal government. The level of state for Education, Culture and Science Ministry of Works Ministry has the institution concerned to carry out the training work may have different names in different states. Large differences between states and provinces avoid Educational and Cultural Affairs of the Standing Conference of Ministers for coordination of the education system has the power to take decisions aimed at being together. Standing Conference of the Ministers of Education and Cultural Affairs via the exchange of ideas among all states in the states concerning important issues is provided (Eurydice, 2009).

In each state, school supervisors are responsible for the inspection and supervision work within the school system. Teachers are responsible for teaching jobs in every school board and the school board in charge of school discipline rules and regulations. These powers can vary by state. Private schools as well as state schools operating in the field of education are also available. According to the basic law, private schools are under the supervision of the state. National educational standards are valid for both types of schools. Private schools, state the different ways in which to get some financial support, but it varies according to the type of school the state from this state to change. $92.9 \%$ of students in public schools according to 2008 data, while $7.1 \%$ are studying in private schools (Eurydice, 2009).

In Germany schools are covered under two headings as general and vocational education. General education, preschool education, primary education, secondary education (1st and 2nd level) and the higher education consist of four stages. Pre-school education in Germany aged 3-6, 6-10 years old (Berlin and Brandenburg, ages 6-12) primary, routing circuit between ages 10-12, $10 / 12-15 / 16$ years of age lower secondary level $15 / 16-18 / 19$ years between the upper secondary (high school) are the stages. Higher age of onset is considered to be 19 or older. Germany is the 9 -year compulsory education covers primary and lower secondary level.

Pre-school education outside the formal school system is given to children in the 3-6 age groups, optionally. The most common in pre-school educational institutions "Kindergarten" in the name are the main schools. In general, the main schools to churches, associations, are dependent on the unions and welfare organizations or municipalities. Despite these schools rely on large public financial aid and other funds, also have children from their families are demanding their financial support. More training is being implemented aimed at socialization, family education support, to complete, to overcome the shortcomings of the development of children is the duty of the school to prepare them for school by providing them better education opportunities and development (Sözer,1997).

All students are usually given in elementary school, covering the first four classes of the mandatory first step of joint training for all states. Berlin and "Brandenburg" state of "Grundschule" consists of six years. After primary school students interested in, based on their ability and success in the fourth (last) at the end of the first half of the classroom teacher and the school principal decided to continue their secondary education at one primary school. Basically the decision in directing school students and the views of students and parents should be taken into account. The final decision must be made by the parents to present to school or school officials. To enter into some type of school depends on the capacity of students to the school or to have a certain level of proficiency. Mostly, outstanding students in high school to prepare for academic learning; 42 that the level of educational achievement in the basic education schools that qualified vocational training to prepare students for successful preparatory middle-level and lower-level vocational schools in lower secondary school students are directed (Sozer, 1997). 
In primary education, after studying in the same class of students at different levels (1-4 classes, Berlin and Brandenburg 1-6 classes) secondary school level (5th grade 12 up to 13) offer students a variety of school types. Secondary level I and Stage II consists of two stages. Higher education in Germany, universities and equivalent institutions of higher education, music and art colleges, and universities of applied sciences are in. In addition, some states in providing education in accordance with the dual system as a part of higher education institutions of higher education are also available. It is necessary to have a general higher education or vocational higher degree of maturity for university entrance. All candidates who meet the entry requirements can enrol in the courses they choose without being subject to other accepted procedures (Kantos, 2007).

\subsection{Education in the Netherlands}

Dutch education system, the government has both the direction of a local nature center. The education system at the country level are arranged centrally and across the country, a joint training system that moves the center of a nature because it applied to indicate that carries a local nature because it is the responsibility of local government management of schools. Powers and responsibilities relating to the management of the education system in the Netherlands are shared between three competent authorities. At the central level, the educational system on all public and private schools in the authority and responsibility involved the central government on behalf of Education, Culture and Science of the Ministry. However, Ministry of Agriculture and Fisheries is responsible the schools in the agricultural field, agriculture, environment (Ultanır, 2000).

Provinces are given very limited powers and responsibilities. Provincial government, common in their area and formal opportunities for all educational needs and to what extent they meet the educational practices in schools to check whether they act within the legal framework. Local governments, has quite extensive powers in the education system are twofold function of education. While all public and private schools in the district management units that are connected to local governments, they are the contractors of the public schools in the region together. In this regard, local governments, the legal regulations of teaching education in schools, the central decision-making, they are responsible for the implementation arranged in accordance with regional characteristics.

The Dutch education system, one of the most important features specified in Article 23 of the Constitution, the freedom of education. The freedom of education; the freedom to open schools, teaching arrangements and freedom of establishment of schools on the basis they are meant to determine the policy. People, opening schools and religion, have the right to education and training based on their ideological views (Eurydice, 2008).

State and private schools have equal status is another important feature of the Dutch education system. This equality of status has been continued so far in 1917. They have equal status means also to be financed by the state of both types of schools. Private education institutions and schools are not paid at all levels of education. Public and private schools, Education, Culture and follows the curriculum set by the Ministry of Science. A large number of students are studying in private schools in the Netherlands. These organizations can also operate according to religious principles (Ven, 2007).

Primary education system in the Netherlands consists of three education levels, including secondary and higher education. 5-12 years from primary education, compulsory education in Dutch secondary education for students between 12-17 years of age. Compulsory Education Act, 17 children under the age of full-time they finish their compulsory education, must attend school at least one day per week part-time. 4 years in the Netherlands there are no formal pre-school institutions for children. Pre-school education is given in mixed game groups and day-care centers. Games for children in the 2-4 age groups are 2.5-4 hours a day and are open 3 days a week. Playgroups are limited to 12-14 students. These institutions are supported in part by the state and private ones as those supported. In addition, families will be asked to be involved. Starting from six weeks of maintenance service centers are up to 4-5 year olds. These centers are 7:00 to 18:00 is open on certain days of the week or five days a week between the hours of children goes to these centers. Health benefits of this type of child care centers, are provided by the Ministry of Social Welfare and Sports, has the participation of families and are financed by private sources. In this stage, it seems inadequate education for children less educated who are funded by the state for the education of children, families and minorities. The purpose in taking early measures of children is to start school and to resolve this problem (Gulcan, 2005).

Primary education lasts for 8 years and encompasses the age group 5-12. While it would be five years since the start of primary school children in primary law, it is allowed to the four-year-old children starting primary school students as an optional 99\% of 4-year-old starts. Primary education "Basis school" are called in the basic school. Each primary school age groups is divided into eight classes. However, every school may occur in different age groups because it has the right to decide on matters with regard to their own arrangements of classes. The first four years of small classes, arrangements can be made as large class in the last four years but those who want to take three small, medium and large and can also group students as in $1-3$, in the form of 4-6 and 7-8. The possibility to switch between groups of students can be taken into consideration according to different levels of success (Ultanir, 2000). 
In the Netherlands, they continued in the 12-18 age groups of the students after the primary and secondary, purpose and duration of the implementation of a variety of different places is an educational training program. General and is divided into two main areas, including vocational education. Secondary education is free up to 18 years. Higher education system in the Netherlands, academic higher education at a university consists of professional higher education and Open University education. A person needs to have the general or vocational secondary education diploma for entrance to higher education and some schools may also specify special entry requirements out of it. In university education, as well as expertise with theoretical studies with training in law and medicine is given. Vocational higher education, educational theory and practice are given to occupations that require high professional competence. High-term master training is 1 or 2 years. 1 or 2 years at the university master, doctorate lasts 4 years. Medicine, Agriculture, Pharmacy 3 years (total 6) and Dentistry at 2 years (total of 6), was organized (Eurydice, 2008).

According to the information given above, the comparison results in Turkey, the education business in Germany and the Netherlands are seen as the responsibility of the ministry of education. However, unlike Germany and the Netherlands all powers in the hands of the Ministry of National Education and the education system in Turkey is managed directly from the central and execution, weight and responsibility of state governments in Germany is over. Education centre in the conduct of government affairs, states and municipalities, are obliged to fulfil their responsibilities defined by law. In the Netherlands, the school management is mainly responsible for local governments. Also, freedom to schools in the Netherlands is well-known in the broad sense. Germany and Turkey training systems involve pre-school, primary, secondary, consisting of four drills, including higher education. The Dutch education system, primary education, secondary education consists of three education levels, including higher education. Unlike Germany and Turkey in the framework of pre-school education system in the Netherlands it is not intended for their own training step. Pre-school education is provided in the non-official institutions.

\section{Discussion}

Turkey, the European Union member is in the process of teaching a foreign language has gained pace and foreign language courses has taken its place among the compulsory public courses. In the academic year 1997-1998 to be implemented in accordance with the eight-year Compulsory Education of foreign language teaching in primary schools as a compulsory subject was put on the 4th and 5th grade. Thus, the primary school in grade 4 in Turkey, students of compulsory foreign language begin at age 10 and continue until 8th grade middle school.

In Germany, the state of primary education varies according to the onset of foreign language teaching. Some states are reduced to the 1st and 2nd class, while others are in the 3rd and 4th grade. But in general compulsory foreign language teaching starts from 3rd grade and is given a four-year school in the last two years. Because it is the primary foreign language teaching for six years, in the state of Berlin, it starts in 3rd grade is given to the 5th and 6th classes and includes a total of four years in. Compulsory foreign language teaching to children in Germany is starting from the age of 9 (The Education System in the Federal Republic of Germany, 2007).

Foreign language teaching in the Netherlands, the last two classes of the primary school under the compulsory foreign language in grades 7 and 8 are given. Applications of different foreign languages in primary schools in the Netherlands are also available. Primary 7 and again these last two classes other than English mandatory taught in 8th grade accelerated English and CLIL applications are also available. Schools also have the freedom to start teaching a foreign language earlier. The start of foreign language teaching may be reduced to 5 or 1 class. Accordingly, beginning in grade 5 or 6 early foreign language at an early age with 1 starting from grade foreign language teaching applications are also available. Language education in the Netherlands has increased the number of schools getting started early. In 2007, 121 primary schools in early foreign language teaching often with English as a foreign language have been launched. These schools are supported by the European Union and efforts are made to improve the early foreign language learning and teaching foreign languages in primary education.

In all three countries, English is the only compulsory foreign language courses at the primary level. When we look to the time allocated to foreign language teaching in Germany (Berlin sample) it increases progressively in the allotted time for language teaching and seems to last five hours out of the classroom. Accordingly, Germany is more than separating the country to teach foreign languages.

Turkey, also taught English as a foreign language compulsory from the 4th grade in elementary school. Compulsory foreign language lessons in order to supplement or be included in a second foreign language course as an elective foreign language courses in accordance with the applicable foreign language level of the students outside of class hours growers course programs. in 4th and 5th grades of primary schools, not to exceed 10 hours per week, not effecting grade passing and be as a course nature preschool educational institutions 5 and 6 age groups of primary school 1,2 and 3 classes of foreign language teaching activities program may apply.

Germany is preferred English as the main foreign language in primary education. Very few schools to include another 
foreign language and all students are required to learn English at any stage of their education. English teaching in primary schools is becoming more widespread. This development is shown as a result of achieving unity with the European Union. Even kindergarten teaching is done in English. However, it is generally done before the primary. Previously schools were not necessarily in English and said that each state also is among the compulsory subjects of English. However, efforts are made to take place among the compulsory subjects of English in all primary schools because you have included among the compulsory courses in foreign language teaching in the European Union.

English is taught as a compulsory foreign language in the Netherlands. To take place in primary education in English, it is based on the European Union's education policy and principles of language acquisition at an early age to be more effective compulsory foreign language teaching 2 hours per week in the Netherlands (in hours) does not exceed. Schools of English courses to choose from 30 minutes to an hour by dividing into two classes can be an hour or two courses a day. Accelerated courses are taught in a couple of hours a week teaching English and CLIL practice.

\section{Research Areas}

Golcuk (2003) states in his study named as "Turkey and Germany instance, in A Critical Approach Based Language Teaching the Teachers 'Perceptions in Turkey" foreign language teaching in Turkey by detecting the status of today, to determine where to come and missing in Turkey to help troubleshoot removed out' Best foreign language teaching, the teaching of foreign languages as compared with Germany, and in this context, also a teacher of foreign language courses in Turkey, there has been a conclusion about how it should be. According to the survey; The absence of opportunities to go to a country that speaks the language of the native language they are learning a foreign language teacher, they could not for reasons of economic books need to improve themselves and to the in-service training because of insufficient, it is necessary for teaching an effective foreign language radio, cassette, video, overhead projector, slide, computer and so on. It was found that the use of tools, even though they are present in most schools. In addition, failure and overcrowded classrooms in the number of classrooms, lessons which prevents event processing, insufficient textbooks used in foreign language courses, courses to ensure that up to date texts and student motivation in the book is found inadequate the effort required.

Buge (2005) points out that content, education, and a comparison of their test status was intended to demonstrate the similarities and differences. According to the survey, it is a framework program of the Finnish Foreign Language Program and content in which we outline, but, according to the rated language proficiency scale incrementally expected behaviour from students is very clear, it was found that observable and measurable manner stated. The target program in Finland, language proficiency related to the four language skills, study strategies, cultural communication skills and communication strategies have been found to be grouped under four main headings. The program targets in Turkey, the students give a specific grammatical structure of knowledge, comprehension of this information and these structures were determined to be directed to uses in certain situations. Finland Foreign Language Program benefited from the creation of the Council of Europe's Common Reference for Languages and the language proficiency in this document has been found to adapt to the school system. Finland Program, is a framework program qualifications only issues and themes, as indicated in the basic structure of Turkey in the content of the program, functional course design is in accordance with regulation, has been found where the structures and vocabulary around the function. Finland teaching duties of disclosure on education given the nature of the program objectives under the title, while in Turkey it was determined that the program shall include information on education. Turkey Program is to assess the status of the test product, while in Finland it was determined that the program evaluation process also important.

Emin (2005) compared Turkish course program that of Macedonia to identify the developments in Turkey and Macedonia middle school applied in the Turkish Republic in terms of comparing the course of the program, the program elements are intended to reveal the similarities and differences between them. According to the survey; When the Republic of Macedonia so far made program development work, adding to the previous program or programs created or prepared by making some changes have been identified. Turkey and Macedonia Elementary second grade in the examination of the Turkish curriculum, it was determined that there are more similarities than differences between them. Korkmaz (2005) mentioned the principles on which the educational system and purposes, the organization of education systems, management and inspection of teachers cultivating, training staff, the planning of training and funding comparing been trying to do in terms of implications for our education system.

Ozgen (2005) compared Elementary Computer Course program applied in Turkey with members of 15 countries of the European Union; Germany, Austria, Belgium, Denmark, Finland, France, the Netherlands, Ireland, Spain, Sweden, Italy, Luxembourg, Portugal, Greece, United Kingdom (England, Wales, Northern Ireland) and then, England primary school 1st and 6th class computer courses compared with the 4th and 5th grade elementary school curricula Turkey has introduced the current situation in Turkey. As to Durna (2007), comparing the social studies subjects in primary schools is quite difficult to identify similar and different aspects. In the study, the first to be informed about the overall structure 
and functioning of the two systems and then tried to examine issues of social information in both systems. According to the results obtained in the study; Lander in Germany with training activities conducted jointly by central government, central management of training activities in the absence of having too much to mention, it was seen to be effective mainly in educational activities of the State in this regard. Both countries, which led to the difference in being subjects of different school programs, social studies classes given turned into a branch of the German education, history and geography are committed as a separate course, and even the 9th grade social studies classes in other senior, history, and as the geography lesson as it has been shown to be as a separate course. The similarities in subject matter, though, have been found to be more than differences.

Kaytan (2007) handled the mathematics curriculum aims to reveal the names of the countries have similarities and differences. According to the survey; Singapore and Turkey Primary Mathematics program was divided according to the subject of the target and that given in the description of the teaching, and the United Kingdom Mathematics program offered should be taught how generally be expressed in target schools in the context of these general objectives are determined to create their own programs. In addition, Turkey Mathematics Curriculum objectives of Singapore and the UK more than the target and the detailed, Singapore and the United Kingdom, physical facilities, in terms of the use of information and communication technology that is more advanced than Turkey, test cases are concerned, Singapore and the UK orientation of national exams, the national exam in Turkey, where the selection and for the placement, the importance of the evaluation process in all three countries, but it is determined that there is insufficient guidance for the use of correct and appropriate the process of assessment tools in Turkey.

Aslan (2008) states that at an early age in other countries, our country and foreign language practice conditions and to compare the application to describe teachers and methodological issues in this matter and to make recommendations. According to the comparison results, the main reasons for the failure in foreign language teaching practice at an early age in Turkey, primary and secondary education institutions and a lack of continuity in foreign language teaching by providing coordination, weakness of the quality of the teachers who teach foreign languages, type of school foreign language teaching, the student's age and development characteristics, objectives of foreign language courses, not to avoid decomposition in the light of the content and methods of teaching and methodology are given and cannot be used as the required course materials in accordance with these characteristics. Due to these mentioned reasons, he had proposed to eliminate the causes of the failure of researchers.

Tok and Aribas (2008) emphasized in his study to provide information about language teaching in EU countries. In addition, the foreign language teaching foreign language teaching in Turkey in the EU countries are examined comparatively in terms of some variables. According to the survey; all European countries, making it an essential part of the foreign language teaching curriculum first foreign language they have begun to teach at an earlier age, the duration of compulsory education in most EU countries, everyone at least two languages can be learned, while in Turkey the duration of compulsory education is only taught in a foreign language, students in primary education in most of the EU countries to learn a foreign language at least half and also in Turkey whereas primary education is the most widely taught language is English, foreign languages in the EU in the primary school of educational extracurricular teachers (classroom teachers), secondary school in the by subject teachers done that, the English lessons in primary schools in Turkey have been given by both stages in the branch teachers, foreign language teaching in the EU countries where priority is given to speaking and listening skills at the start, to foreign language teaching classroom norms (class features such as available) as determined in a few countries and a maximum class norms or the number of students in the group are determined can vary from country to country.

Yazici (2009) laid emphasis on the historical process of the educational systems of both countries, based on the education system, the structure of the education system, examined teachers' upbringing and education planning and terms of financing. According to the data reached at the end of the study; The Ministry of Education in Turkey is a very bureaucratic structure, and the training in Canada bureaucratic not authority and responsibility is left to the lower unit, Canadian education system, students that meet the needs of students interested in the Turkish education system, needs, skills and expectations cannot be placed on a priority base, in Canada in Turkey to meet all the educational needs of the budget allocated to education is that there is very limited educational resources, Canada training System is more emphasis on pre-school education and the place of serious study in this field in Turkey in 2009, the value given to pre-school it was found that it improved and made compulsory pre-school education.

European education system lay emphasis on modern languages, including a drive for all Europeans to be competent in their native language plus two other languages. The dominant model of language teaching at a European level is one of Communicative Competence, with interest growing in integrating language awareness and intercultural awareness approaches within this model. The Department of Education and Science has worked with the Council of Europe to develop a Language Education Policy Profile and is currently working towards developing a Language Education Policy for Ireland. The Primary School Curriculum recommends that one-third of teaching time is attributed to teaching 
language. In the case of English, teachers highlighted challenges with the writing strand, and prioritised developing children's writing skills, followed by oral language skills and reading skills. These findings were in line with other research conducted on English and the English Curriculum, where low-levels of literacy were reported (DES, 2005c; Eivers, Shiels \& Shortt, 2005a).

\section{Conclusion}

While language education for all could form a common strand for all schools, competency models should be facilitated in schools in which appropriate provisions are in effect. The curriculum experts of the countries go on to work on plans and new programs for the language strand of the Primary school. The work within the language strand will start to make headway towards exploring short-term objectives outlined in the study.

As to Saricoban (2012), English has now become an indispensable part of foreign language teaching, thus, the Turkish government has taken a number of initiatives, particularly in revising the curriculum, teaching methods, teacher training and teacher education institutions. In reaction to the changing economic and political situations of the country, the government has increasingly been concerned with educating its citizens who will be able to adopt and learn new language skills at different levels in their educational lives. Although, resources and efforts have been expanded on the provision of English at the level of primary and higher education, policy objectives are not in concert with instructional practices.

Germany's foreign language program is based on a framework curriculum and the Netherlands' curriculum is defined clearly in terms of all aspects, especially objectives. The curricula of Germany and the Netherlands provide more freedom with teachers in planning lessons and meet the needs and interests of students as well. In all three countries, the programs vary in terms of content presentation. Turkey has a detailed content of the English curriculum, and teachers are obliged to follow the program. On the other hand, teachers in the Netherlands are given the opportunity to make the choice of content. Teaching process is clearly stated in Germany and the Netherlands regarding methods and techniques of teaching English programs available and decide on the selection of appropriate methods and techniques for teaching task is left to the teacher. Turkey ranked the methods and techniques used in the English program, but there is no description about where and how to use them. In all three countries it is included in the assessment of products and processes.

Foreign language education is vital to a country's success in the world of the future: a world that will insist upon their need to interact effectively with others who do not speak English. It is critically important that schools, elementary through post-secondary, offer our students that opportunity to develop those skills. Students should be backed up as language learners across the curriculum, and helped to build on this at post-primary level. There should be a reinforced focus on language awareness in the primary school foreign language curriculum, which can be integrated into current language time. In addition, teachers should be supported in their methodology and assessment in English.

\section{References}

Akinbote, O. (2001). The Nigerian Primary School Teachers: Angels of instruction or devils of destruction? Ibadan: Ibadan University Press.

Aslan, N. (2008). Foreign Language Practices in the World and the Situation in Turkey. Cukurova University Journal of Education Faculty, 3(35), Fall 2008.

Basaran, I. E. (1994). Education System in Turkey. Second Edition. Ankara.

Bruns, B., Mingat, A., \& Rakotomalala, R. (2003). Achieving universal primary education by 2015: A chance for every child. Washington, D.C: The World Bank. http://dx.doi.org/10.1596/0-8213-5345-4

Buge, B. C. An Examination of the Comparison of Turkey's Primary School English Curriculum and Finland's Foreign Language Curriculum (2005). (Unpublished Master of Arts Thesis). Hacettepe University, Social Sciences Institution, Curriculum and Instruction Sub-Department, Ankara.

Candelier, M., (2004). The Introduction of Language Awareness into the Curriculum Workshop No 1/2002 Report ECML http://www.ecml.at/activities/projectdetails.asp?p=8 Accessed: 20/03/16.

Department of Education and Science, (2005c). Literacy and Numeracy in Disadvantaged Schools: Challenges for Teachers and Learners. An Evaluation by the Inspectorate of the Department of Education and Science. Dublin: The Stationary Office.

Durna, N. I. (2007). Comparison of Subjects in Social Knowledge Course At Schools in Turkish-German Education Systems (the Bavarian state). (Unpublished Master of Arts Thesis). Nigde University, Social Sciences Institution, Social Knowledge Department, Nigde. 
Emin, O. (2005). Comparison of Secondary School Programs the Turkish Language Teaching Course in Turkey and in Macedonia. (Unpublished Master of Arts Thesis). Hacettepe University, Social Sciences Institution, Curriculum and Instruction Sub-Department, Ankara.

Erdem, M. (2007). Turkish Education System. A. Balci (Editor). Comparative Education Systems: $1^{\text {st }}$ Edition. Ankara: Pegem A Publications.

Eurydice European Commission (2008). Organizing Turkish Education System. Education, Audio-visual and Culture Executive Agency.

Eurydice European Commission (2009). National Summary Sheets on Education System in Europe and Ongoing Reforms. Germany.

Golcuk, B. (2003). A Case Study: A Critical Perspective on the Opinions of Teachers in Foreign Language Education in Turkey and Germany. (Unpublished Master of Arts Thesis). Anatolia University, Eskisehir.

Gulcan, M. G. (2005). EU and the Process of Education. Ankara: Ani Publications.

Kantos, Z. E. (2007). Education System in Republic of Federal Germany. Comparative Education Systems: $1^{\text {st }}$ Edition. Ankara: Pegem A Publications.

Kaytan, E. (2007). Comparison of Turkey, Singapore and England's Mathematic Curricula. (Unpublished Master of Arts Thesis). Hacettepe University, Social Sciences Institution, Curriculum and Instruction Sub-Department, Ankara.

Korkmaz, T. (2005). Comparison of Turkish and British Education Systems. (Unpublished Master of Arts Thesis). Uludag University, Social Sciences Institution, Curriculum and Instruction Sub-Department, Bursa.

MEB (2006). Turkey and European Countries' Education Systems. Turkish Republic Ministry of Education Office of Foreign Affairs Productions: Kalkan Publications Press, Ankara.

MEB (2010). Organizing Turkish Education System. Ankara: State Books Capital Management

Ozgen, C. (2005). Comparison of Primary School Computer Course Curricula of 15 Member Countries in European Union and Evaluation of the Situation in Turkey. (Unpublished Master of Arts Thesis). Ankara University, Social Sciences Institution, Curriculum and Instruction Sub-Department, Ankara.

Saricoban, G. (2012). Foreign language education policies in Turkey, Procedia-Social and Behavioral Sciences 46, WCES. http://dx.doi.org/10.1016/j.sbspro.2012.05.539

Sozer, E. (1997). Education in Three European Countries: Germany, Denmark and France Education Systems. Eskisehir: Anatolia University. No: 1004. Education Faculty Publications, 47.

Tok, H., \& Aribas, S. (2008). Foreign Language Education in the Process of Compatibility to the Membership of European Union. Inonu University, Education Faculty Journal, 9, 205-227.

Ultanir, G. (2000). Comparative Science Education: Principles and Techniques. Ankara: September Books and Publications.

Ven, B. (2007). Netherlands in W. Horner, H. Dobert, B. Von Kopp and W. Mitter (Eds.), The Education Systems Of Europe. (P. 555-572). Springer Netherlands.

Yazici, I. (2009). Comparison of Turkish and Canada Education Systems. (Unpublished Master of Arts Thesis). Yeditepe University, Social Sciences Institution, Curriculum and Instruction Sub-Department, Educational Administration and Supervision Department, Istanbul.

Yildirim, M., C. (2010). The Administrative Structure of Education Systems in Turkey and European Countries. Kastamonu Education Journal, 18(2), 567-586. 